\title{
Kewenangan Notaris dalam Mensertifikasi Transaksi yang Dilakukan Secara Elektronik (Cyber Notary)
}

\author{
Ni Kadek Ayu Ena Widiasih ${ }^{1}$
}

1 Program Studi Magister (S2), Kenotariatan Fakultas Hukum Universitas Udayana, Bali Indonesia, E-mail: ayuenaannabeth@gmail.com

\begin{tabular}{l}
\hline Info Artikel \\
\hline Masuk :31 Januari 2020 \\
Diterima : 2 Februari 2020 \\
Terbit : 30 April 2020 \\
Keywords : \\
Authority of the Notary; \\
Certification; Cyber Notary \\
\\
\\
Kata kunci: \\
Kewenangan Notaris; \\
Sertifikasi; Cyber Notary \\
Corresponding Author: \\
Ni Kadek Ayu Ena Widiasih, \\
E-mail: \\
ayuenaannabeth@gmail.com \\
DOI : \\
10.24843/AC.2020.v05.i01.p13
\end{tabular}

\section{Info Artikel}

Diterima : 2 Februari 2020

Terbit : 30 April 2020

Keywords :

Authority of the Notary; Certification; Cyber Notary

Kata kunci:

Kewenangan Notaris,

Corresponding Author:

Ni Kadek Ayu Ena Widiasih,

E-mail:

10.24843/AC.2020.v05.i01.p13

\begin{abstract}
Based on the Elucidation of Article 15 paragraph (3) of The Act of Notary Position, a notary has the authority to certify transactions that are done electronically (Cyber Notary). From the Elucidation of Article 15 paragraph (3) of The Act of Notary Position, there is no explanation of the authority of a notary in certifying transactions that are done electronically, with no explanation of the word "certification" creates an ambiguity in legal norms. The writing of this study aims to determine the authority to undertake a certification by a notary public in transactions that are done electronically. Normative legal research methods is uses for this writing. This paper conclusion is a Notary based on the Elucidation of Article 15 paragraph (3) The Act of Notary Position has the authority to certify transactions that are done electronically. The authority to undertake the certification is as same as the Notary's authority in the provisions of Article 15 paragraph (2) letter " $a$ " The Act of Notary Position or it can also be called the authority to legalize, namely giving authority to the Notary to ensure that the signature on the electronic certificate that is valid signature of the parties, ensure the validity of status and identity the parties, and ensure the date on electronic certificate.
\end{abstract}

\begin{tabular}{l}
\hline Abstrak \\
\hline Berdasarkan Penjelasan Pasal 15 ayat (3) UUJNP notaris \\
memiliki kewenangan mensertifikasi transaksi yang dilakukan \\
secara elektronik (Cyber Notary). Dari Penjelasan Pasal 15 ayat \\
(3) UUJNP, tidak terdapat pemahaman lebih lanjut mengenai \\
kewenangan mensertifikasi yang dimiliki oleh notaris, tidak \\
terdapatnya penjelasan mengenai maksud kata mensertifikasi \\
tersebut menimbulkan kekaburan norma hukum. Tulisan ini \\
bertujuan untuk mengetahui kewenangan melakukan sertifikasi \\
yang dimiliki notaris. Penulisan ini menggunakan metode \\
penelitian hukum normatif. Hasil penelitian ini menunjukkan \\
bahwa kewenangan Notaris dalam mensertifikasi transaksi yang \\
dilakukan secara elektronik sama dengan kewenangan Notaris \\
dalam ketentuan Pasal 15 ayat (2) huruf a UUJNP atau yang \\
dapat juga disebut dengan kewenangan untuk melakukan \\
legalisasi, yaitu memberikan wewenang kepada Notaris untuk \\
memastikan tanda tangan yang ada pada sertifikat elektronik \\
tersebut adalah benar tanda tangan dari para pihak, memastikan \\
kebenaran status dan identitas dari para pihak, serta memastikan
\end{tabular}


tanggal pada sertifikat elektronik tersebut.

\section{Pendahuluan}

Perkembangan teknologi dan informasi kearah yang lebih maju pada saat ini menimbulkan berbagai perubahan terhadap kegiatan manusia yang mencakup berbagai bidang kehidupan yang kemudian mempengaruhi lahirnya suatu perbuatanperbuatan hukum yang baru. Perkembangan teknologi informasi serta perbuatanperbuatan hukum yang baru seperti transaksi elektronik kemudian berkembang dan melanda berbagai penjuru dunia sebagai akibat dari adanya arus globalisasi. Kemajuan dan perkembangan teknologi tersebut kemudian menimbulkan perubahan dalam tatanan organisasi maupun hubungan sosial kemasyarakatan. Perubahan tatanan organisasi maupun hubungan sosial kemasyarakatan tersebut dapat dilihat dari adanya suatu bentuk perpaduan atau konvergensi sebagai akibat lain dalam perkembangan teknologi.

Pengaruh dari adanya kemajuan teknologi tersebut kemudian menuntut segala sesuatu hal menjadi lebih mudah serta menuntut adanya keefektivan, kecermatan, dan keefisiensian dalam segala perbuatan yang dilakukan tanpa adanya hambatan ruang dan waktu. Tuntutan tersebut kemudian melahirkan suatu perbuatan hukum baru yang juga tidak terlepas dari adanya pemanfaatan teknologi dan informasi yang berkembang. Dalam bidang pelayanan jasa, khususnya dibidang kenotariatan kemudian berkembang suatu konsep baru dengan pemanfaatan teknologi, informasi dan komunikasi yang disebut dengan cyber notary.

Istilah cyber notary merupakan suatu istilah yang terdapat dalam sistem hukum Common Law, istilah tersebut kemudian dipopulerkan oleh negara yang memberlakukan sistem hukum tersebut melalui ahli hukumnya. Berbeda sistem hukum yang dipergunakan juga menimbulkan perbedaan istilah yang dipergunakan, tidak seperti sistem hukum Common Law, penggunaan istilah yang serupa dengan cyber notary tersebut pada sistem hukum Eropa Kontinental disebut dengan istilah "e-notary". Berdasarkan pada hal tersebut, apabila ditinjau dari sistem hukum yang dipergunakan, maka dirasa lebih tepat apabila pada negara Indonesia istilah yang dipergunakan adalah "e-notary" atau "electronic notary" mengingat sistem hukum yang dipergunakan di Indonesia adalah Eropa Kontinental. Istilah E-notary sendiri sesungguhnya memiliki esensi yang serupa dengan istilah cyber notary, esensi dari istilah "e-notary" adalah adanya penyajian independen record oleh suatu pihak pada suatu transaksi yang dalam pelaksanaannya dilakukan oleh para pihak menggunakan media elektronik. ${ }^{1}$

Istilah cyber notary terdiri dari dua kata yaitu kata cyber dan notary. Cyber berasal dari kata cybernetic, dikembangkan oleh Norbert Wiener yang memiliki arti sebagai perpaduan antara beberapa bidang ilmu seperti elektro, matematika, robotik,

1 BENNY, B. (2015). Penerapan Konsep Cyber Notary di Indonesia Ditinjau dari Undang-undang Nomor 2 Tahun 2014. PREMISE LAW JURNAL, 5. 
juga prikologi, ${ }^{2}$ dan notary yang dalam bahasa Indonesia berarti notaris. Pengertian notaris dapat dijumpai pada ketentuan Pasal 1 angka 1 Undang-Undang Nomor 2 Tahun 2014 Tentang Perubahan Atas Undang-Undang Nomor 30 Tahun 2004 Tentang Jabatan Notaris (yang selanjutnya disebut dengan UUJNP), yaitu adalah "pejabat umum yang berwenang untuk membuat akta autentik dan memiliki kewenangan lainnya sebagaimana dimaksud dalam Undang-Undang ini atau berdasarkan undangundang lainnya".

Pada pemanfaatannya, dunia baru yang tercipta dari perkembangan teknologi atau dunia maya (cyber space) yang diciptakan oleh cyber notary dapat mendatangkan berbagai keuntungan. Keuntungan tersebut dapat diperoleh tanpa adanya hambatan ruang dan waktu. Pada dasarnya konsep cyber notary memiliki makna sebagai penggunaan teknologi informasi dalam menjalankan kewenangan atau tugas jabatan yang dilakukan oleh notaris. ${ }^{3}$ Dengan adanya konsep cyber notary tersebut dapat dikatakan memberikan suatu keuntungan berupa kemudahan-kemudahan yang diperoleh oleh seorang notaris ketika melaksanakan tugas jabatannya, dimana hal tersebut sejalan dengan kemudahan yang dapat diperoleh sebagai dampak yang menuju ke arah positif dari perkembangan teknologi saat ini.

Di Indonesia, ketentuan mengenai cyber notary dapat ditemukan dalam Pasal 15 ayat (3) UUJNP, yaitu "notaris memiliki kewenangan lain yang diatur dalam peraturan perundang-undangan". Penjabaran mengenai kewenangan lain tersebut kemudian dapat ditemukan pada Penjelasan Pasal 15 ayat (3) UUJNP yaitu "kewenangan mensertifikasi transaksi yang dilakukan secara elektronik (Cyber Notary), membuat Akta Ikrar Wakaf, dan hipotek pesawat terbang". Namun, dari Penjelasan Pasal 15 ayat (3) UUJNP tidak terdapat pengaturan lebih lanjut atau penjelasan mengenai seperti apa bentuk kewenangan notaris dalam melakukan sertifikasi tersebut.

Kata mensertifikasi dalam Penjelasan Pasal 15 ayat (3) UUJNP menimbulkan berbagai penafsiran seperti menyamakan kata mensertifikasi dengan memverifikasi, menimbulkan penafsiran mengenai bentuk kewenangan mensertifikasi yang dilakukan oleh notaris, serta menafsirkan kata mensertifikasi tersebut sebagai pembuatan sertipikat terhadap transaksi atau perbuatan hukum yang dilakukan melalui media elektronik oleh notaris, sehingga dalam hal tersebut terdapat suatu kekaburan norma hukum. Suatu aturan hukum dapat dikatakan baik, apabila hukum tersebut dapat memberikan kepastian hukum. Apabila dalam aturan hukum tersebut menimbulkan multitafsir atau norma kabur, tentunya hukum tersebut tidak dapat memberikan suatu kepastian hukum. Rumusan masalah yang dikaji dalam penelitian ini adalah bagaimanakah bentuk kewenangan notaris dalam mensertifikasi transaksi yang dilakukan secara elektronik (cyber notary)? Penulisan penelitian ini memiliki tujuan untuk mengembangkan keilmuan dalam bidang hukum kenotariatan serta untuk mengetahui bentuk kewenangan mensertifikasi transaksi yang dilakukan secara elektronik oleh notaris dalam aspek cyber notary.

${ }^{2}$ Mansur, D.M.A., \& Gultom, E., (2009), Cyber Law, Aspek Hukum Teknologi Informasi, cet2, Bandung: Refika Aditama, h. 122.

${ }^{3}$ Nurita, E. (2012), Cyber Notary Pemahaman Awal Dalam Konsep Pemikiran, Bandung: PT Refika Aditama, h. 4. 
Penelitian terdahulu yang terkait dengan penelitian ini, dilakukan oleh Desy Rositawati pada tahun 2017, menunjukkan bahwa istilah cyber notary memiliki cakupan yang luas dan memiliki kaitan dengan penggunaan maupun pemanfaatan teknologi informasi oleh notaris dalam melaksanakan tugas jabatannya. Dalam penelitian tersebut penyimpanan protokol notaris secara elektronik yang memanfaatkan kemajuan teknologi dalam kaitan cyber notary dapat memberikan dampak positif apabila dilihat dari aspek ekonomis yaitu lebih praktis, efisien, murah dan aman, serta dari aspek hukum yaitu dapat membantu atau memudahkan dalam proses hukum terkait hukum pembuktian seperti alat bukti elektronik. ${ }^{4}$ Kemudian, Carisma Gagah Arisatya pada tahun 2015 melakukan penelitian mengenai pelaksanaan kewenangan mensertifikasi transaksi yang dilakukan secara elektronik oleh notaris di Kota Malang, namun dalam penelitian tersebut pelaksanaan kewenangan notaris dalam mensertifikasi transaksi tersebut belum dapat terlaksana sebagaimana yang telah diatur dalam UUJNP karena terhambat oleh beberapa Peraturan Perundang-undangan yang telah ada di Indonesia serta kewenangan melakukan sertifikasi transaksi tersebut akan menghasilkan akta dibawah tangan yang kemudian dilegalisasi oleh notaris. ${ }^{5}$ Hal yang serupa juga dikemukakan oleh Benny pada tahun yang sama, dalam penelitian tersebut menunjukkan bahwa penerapan konsep cyber notary berdasarkan Penjelasan Pasal 15 UUJNP dapat meliputi kewenangan dalam mencetak dan melegalisasi surat dan /atau mencetak sertifikat yang dicetak melalui sistem Direktorat Jenderal Administrasi Hukum Umum online . ${ }^{6}$

\section{Metode Penelitian}

Kekaburan norma hukum pada kata mensertifikasi terkait kewenangan yang dimiliki oleh notaris menjadi dasar dilakukannya penelitian normatif ini. Penelitian ini menggunakan 2 (dua) pendekatan, yaitu pendekatan konsep (the consepttual approach) dan pendekatan Frasa (Words and Phrase Approach). Sumber bahan hukum yang dipergunakan terbagi menjadi 3 (tiga), yaitu bahan hukum primer (meliputi jurnal nasional, jurnal internasional, tesis, maupun disertasi), bahan hukum sekunder, serta bahan hukum tersier (kamus hukum. Teknik bola salju merupakan teknik yang dipilih penulis sebagai teknik yang dipergunakan untuk mengumpulkan bahan hukum, yaitu dengan melihat sumber-sumber yang dipergunakan oleh bahan hukum yang memiliki kaitan dengan penelitian ini. Dalam melakukan analisis dipergunakan 2 (dua) teknik analisis yaitu teknik analisis deskriptif dan teknik analisis secara sistematis.

\section{Hasil Dan Pembahasan}

Istilah Cyber notary oleh Surya Jaya, diartikan sebagai pemanfaatan atau penggunaan teknologi informasi dalam menjalankan fungsi, tugas dan kewenangannya sebagai notaris, contoh dari teknologi informasi yang dimaksud yaitu seperti komputer

4 Rositawati, D., Utama, I. M. A., \& Kasih, D. P. D. (2017). PENYIMPANAN PROTOKOL NOTARIS SECARA ELEKTRONIK DALAM KAITAN CYBER NOTARY. Acta Comitas: Jurnal Hukum Kenotariatan, 172-182.

5 Arisatya, C. G. (2015). Urgensi dan Relevansi Kewenangan Notaris untuk Mensertifikasi Transaksi yang Dilakukan secara Elektronik (Studi di Notaris Wilayah Kerja Kota Malang). Kumpulan Jurnal Mahasiswa Fakultas Hukum.

${ }^{6}$ BENNY, B., Op. cit. 
atau jaringan komputer, maupun penggunaan media elektronik lainnya seperti video konferensi atau telekonferensi. ${ }^{7}$ Sehingga dengan demikian, apabila seorang Notaris saat melaksanakan tugas jabatannya, Notaris tersebut menggunakan dan/atau memanfaatkan teknologi informasi, maka hal tersebut sudah dapat dikatakan sebagai cyber notary.

Cyber notary menjadi suatu konsep yang dapat memberikan kemudahan bagi seorang notaris dalam melaksanakan tugasnya, serta cyber notary merupakan suatu konsep yang saat ini mulai diterapkan di Indonesia. Penerapan konsep tersebut dapat dilihat dari dituangkannya istilah cyber notary dalam Penjelasan Pasal 15 ayat (3) UUJNP, dalam pasal tersebut dapat dilihat dengan jelas adanya istilah cyber notary. Adanya pemanfaatan atau penggunaan teknologi informasi oleh seorang notaris dalam melaksanakan tugas dan kewenangannnya tersebut, dapat ditemukan contohnya pada pembuatan suatu risalah rapat dalam Rapat Umum Pemegang Saham (selanjutnya disebut dengan RUPS) Perseroan Terbatas oleh Notaris. Namun terlebih dahulu perlu diketahui bahwa secara umum, akta yang dibuat atau dikeluarkan oleh seorang notaris terbagi menjadi 2 (dua) jenis akta yang berbeda yaitu:

1. Akta Relas

Akta Relas adalah suatu akta yang dibuat atau dikeluarkan oleh seorang notaris, akta tersebut merupakan akta otentik yang dibuat sebagai bentuk dari kewenangan tugas jabatan yang dimiliki. Dalam pembuatan akta, suatu keadaan atau peristiwa yang disaksikan atau segala sesuatu peristiwa yang dilihat maupun dilakukan notaris dapat dijadikan sebagai dasar dalam pembuatan aktanya. ${ }^{8}$

2. Akta Partij

Akta Partij adalah suatu akta yang didalamnya memuat rangkaian lengkap mengenai keterangan yang diceritakan atau diterangkan oleh penghadap, yang kemudian berdasarkan keterangan penghadap tersebut notaris kemudian mengkonstatirnya ke dalam suatu akta otentik. ${ }^{9}$

Risalah Rapat dalam RUPS yang apabila dibuat oleh Notaris, maka risalah Rapat tersebut berjenis akta relas. Pembuatan akta relas dalam RUPS Perseroan Terbatas memiliki kaitan yang erat dengan dengan istilah cyber notary, karena penyelenggaraan RUPS dapat dilakukan dengan menggunakan media elektronik sebagaimana yang diatur dalam Pasal 77 ayat (1) Undang-Undang Nomor 40 Tahun 2007 Tentang Perseroan Terbatas yang menyatakan bahwa "RUPS dapat juga dilakukan melalui media telekonferensi, video konferensi, atau sarana media elektronik lainnya yang memungkinkan semua peserta RUPS saling melihat dan mendengar secara langsung serta berpartisipasi dalam rapat", karena menggunakan media elektronik maka hal tersebut merupakan cyber notary. Akta relas yang dibuat oleh Notaris keabsahannya tetap dapat dipastikan meskipun dalam pembuatannya

7 Wijanarko, F. R., Mulyoto, M., \& Supanto, S. (2015). Tinjauan Yuridis Akta Notaris Terhadap Pemberlakuan Cyber Notary Di Indonesia Menurut Undang-undang Nomor 2 Tahun 2014. Repertorium, 2(2).

8 Wijaya, P. A. P. D. (2018). TANGGUNG JAWAB NOTARIS TERHADAP KESALAHAN DALAM PEMBUATAN AKTA YANG DILAKUKAN OLEH NOTARIS PENGGANTINYA. Jurnal HUKUM BISNIS, 2(2), 36-51.

${ }_{9}$ Gerungan, L. K. (2012). Kekuatan Pembuktian Akta Di Bawah Tangan Yang Telah Memperoleh Legalitas Dari Notaris. 
diselenggarakan menggunakan media telekonferensi, sehingga akta tersebut kekuatan pembuktiannya tetaplah sempurna, sepanjang kewajiban Notaris untuk menandatangani akta tersebut terpenuhi. ${ }^{10}$ Pelaksanaan cyber notary selain dapat dilihat pada pembuatan risalah rapat dalam RUPS Perseroan Terbatas yang menggunakan media elektronik, juga dapat dilihat dari penggunaan komputer dalam pembuatan akta serta pendaftaran akta secara online yang dilakukan oleh Notaris. ${ }^{11}$

Cyber notary dalam pelaksanaannya memberikan tiga layanan yang menurut Saiful Hidayat ketiga layanan tersebut merupakan layanan yang bersifat utama yaitu:

1. Layanan Sertifikasi (certification), yaitu suatu layanan yang diberikan untuk membuktikan identitas dari dokumen elektronik tersebut, seperti misalnya kapan dokumen tersebut dikirim, siapa yang mengirim dokumen tersebut, dan dokumen apa yang dikirimkan tersebut.

2. Layanan Repositori (repository service), yaitu suatu layanan yang diberikan untuk menyimpan dokumen elektronik kedalam suatu server yang aman (secure).

3. Layanan Berbagi (sharing service), yaitu suatu layanan yang diberikan untuk memberikan pelayanan terhadap pihak-pihak yang diizinkan, pelayanan tersebut dilakukan melalui layanan share dokumen elektronik sehingga memungkinkan terjadinya pertukaran secara elektronik. ${ }^{12}$

Berdasarkan pada layanan yang terdapat dalam cyber notary sebagaimana yang dikemukakan oleh Saiful Hidayat tersebut, layanan sertifikasi merupakan layanan yang utama. Kemudian, apabila dilihat dari segi istilah, istilah sertifikasi memiliki arti keterangan atau pengesahan, dimana istilah tersebut bersumber dari kata "certification" dalam bahasa Inggris. Selanjutnya apabila ditinjau dari segi terminologi, kata sertifikasi yang dilakukan secara elektronik memiliki terminologi sebagai pembuatan sertifikat elektronik dari dilakukannya suatu transaksi secara elektronik, serta dalam pembuatan sertifikat tersebut terdapat tiga ciri utama yang sangat terlihat yaitu tanpa harus adanya tatap muka antara para pihak yang melakukan transaksi, borderless, dan paperless. ${ }^{13}$ Kata sertifikasi dapat pula dimaknai sebagai suatu prosedur pemberian jaminan yang dilakukan oleh pihak ketiga dan merupakan kesepakatan para pihak sebagai akibat dari telah dipenuhinya standar tertentu oleh suatu produk maupun proses atas jasa yang dilakukan berdasarkan pada suatu prosedur audit. ${ }^{14}$

Kewenangan Notaris dalam melakukan sertifikasi sebagaimana termuat dalam Penjelasan Pasal 15 ayat (3) UUJNP, memiliki kaitan dengan kata cyber notary yang tercantum dalam ketentuan pasal tersebut. Kata cyber notary yang apabila ditelusuri lebih lanjut, tentunya memiliki kaitan yang erat dengan penggunaan teknologi maupun suatu perbuatan yang memanfaatkan teknologi seperti misalnya transaksi

10 Dharmawan, N. K. S. (2015). Keberadaan Pemegang Saham Dalam Rups Dengan Sistem Teleconference Terkait Jaringan Bermasalah Dalam Perspektif Cyber Law. Jurnal Magister Hukum Udayana (Udayana Master Law Journal), 4(1).

${ }^{11}$ Matra, A. F. (2012). Penerapan Cyber Notary di Indonesia Ditinjau dari Undang-undang Nomor 30 Tahun 2004 tentang Jabatan Notaris (Doctoral dissertation, Tesis, Depok).

12 Nurita, E. Op. cit. h. 21-23.

${ }^{13}$ Arisatya, C. G. (2015). Op. cit.

14 Rossalina, Z. (2016). Keabsahan Akta Notaris Yang Menggunakan Cyber Notary Sebagai Akta Otentik. Kumpulan Jurnal Mahasiswa Fakultas Hukum. 
elektronik. Definisi dari Transaksi elektronik sebagaimana yang dinyatakan dalam Pasal 1 angka 2 Undang-Undang Nomor 11 Tahun 2008 Tentang Informasi dan Transaksi Elektronik, merupakan "perbuatan hukum yang dilakukan dengan menggunakan komputer, jaringan komputer, dan/atau media elektronik lainnya".

Secara elektronik, pelaksanaan transaksi atau perdagangan dilakukan dengan pertukaran informasi oleh para pihak berdasarkan pada perikatan yang telah disepakati.15 Dalam transaksi tersebut, terdapat suatu perpaduan yang berbentuk jaringan kerja (networking), jaringan kerja (networking) tersebut terhubung dengan jaringan komputer yang lebih luas atau global dengan suatu sistem informasi dengan jaringan berbasis komputer yang dapat terhubung melalui suatu jasa telekomunikasi. ${ }^{16}$ Pada dasarnya, dalam transaksi yang dilaksanakan dengan cara elektronik tidak terdapat pertemuan (face to face) yang dilakukan secara tatap muka oleh para pihak, sehingga penggunaan media elektronik dalam suatu transaksi dapat dikatakan akan memberikan keefektifan dan keefisiensian tersendiri tanpa adanya hambatan ruang dan waktu bagi para pihak yang akan bertransaksi sebagaimana yang sering dijumpai dalam transaksi yang dilakukan dengan cara biasa atau konvensional. Sehingga dengan demikian, Notaris dalam melakukan sertifikasi, memiliki kewenangan mensertifikasi suatu perbuatan yang dalam pelaksanaannya perbuatan tersebut menggunakan atau memanfaatkan suatu media elektronik.

Dalam pelaksanaannya sertifikasi memiliki hubungan yang erat dengan keautentikan suatu dokumen. Sertifikasi dapat memperjelas keautentikan suatu dokumen dan keterpercayaan terhadap adanya sistem keamanan informasi dan komunikasi berdasarkan kualifikasi tertentu (quality assurance level), meskipun keamanan suatu informasi atau dokumen elektronik rentan terhadap perubahan. Beberapa hal yang perlu diperhatikan dalam proses autentikasi yaitu:

1. Keabsahan, validitas atau kebenaran identitas dari para pihak dimana dokumen elektronik tersebut berasal, meliputi pihak yang mengirimkan dan yang menerima Dokumen Elektronik tersebut.

2. Kewenangan pihak yang membuat, mengirim dan penerima dokumen elektronik.

3. Validitas atau keabsahan dari perangkat atau peralatan yang dipergunakan dalam pembuatan, penyimpanan, pengiriman, dan penerimaan dokumen elektronik.

4. Validitas atau keabsahan dari proses pembuatan, menyimpan, pengiriman dan menerima dokumen elektronik.

5. Integritas atau jaminan keutuhan dokumen elektronik, memiliki pengertian bahwa dokumen tersebut benar sah atau unik, dibuat tanpa adanya perubahan secara tanpa hak atau wewenang yang dibuat pertama kali untuk keperluan yang dituju. ${ }^{17}$

Dengan demikian, untuk mendukung jalannya proses autentifikasi, maka diperlukan fungsi dan peran dari pihak ketiga (trusted third party) untuk menguatkan

\footnotetext{
${ }^{15}$ Makarim, E. (2003), Kompilasi Hukum Telematika, Jakarta: Raja Grafindo Persada, h. 222.

${ }^{16}$ Ibid. h. 223.

17 Makarim, E. (2015). Keautentikan Dokumen Publik Elektronik Dalam Administrasi Pemerintahan Dan Pelayanan Publik. Jurnal Hukum \& Pembangunan, 45(4), 508-570.
} 
suatu dokumen (mensertifikasi), dimana pihak ketiga tersebut dapat menjelaskan originalitas dan memberikan jaminan keutuhan terhadap suatu informasi atau dokumen elektronik dalam setiap proses pembuatan, menyimpan, pengiriman dan menerima dokumen elektronik, melalui penerbitan suatu pernyataan informasi atau sertifikat. 18

Dalam melakukan sertifikasi, notaris berperan sebagai pihak ketiga yang dipercaya (trusted third party) dalam melegitimasi dan mengamankan transaksi elektronik. ${ }^{19}$ Kemudian, terhadap jalannya suatu lalu lintas transaksi elektronik cyber notary memiliki suatu fungsi utama dalam melakukan autentifikasi dan sertifikasi. Sertifikasi itu sendiri memiliki pengertian bahwa dapat dikeluarkannya suatu digital certificate oleh notaris kepada para pihak yang berkepentingan berdasarkan wewenang yang dimiliki oleh notaris untuk bertindak sebagai pihak ketiga yang dipercaya. ${ }^{20}$

Sertifikat elektronik yang dapat dikeluarkan oleh notaris tentunya harus sesuai dengan sertifikat elektronik yang diatur dalam Peraturan Pemerintah Nomor 82 Tahun 2012 Tentang Penyelenggaraan Sistem dan Transaksi Elektronik. Menurut ketentuan Pasal 1 angka 18, Sertifikat elektronik memiliki pengertian sebagai "sertifikat yang bersifat elektronik yang memuat Tanda Tangan Elektronik dan identitas yang menunjukkan status subjek hukum para pihak dalam Transaksi Elektronik yang dikeluarkan oleh penyelenggara sertifikasi elektronik". Dalam ketentuan pasal tersebut, Tanda Tangan yang berbentuk Elektronik dan identitas yang terdapat dalam sertifikat elektronik memiliki peran yang penting, karena dapat menunjukkan status para pihak sebagai subjek hukum. ${ }^{21}$

Berdasarkan ketentuan pasal tersebut, hanya tanda tangan dan identisas para pihak yang terdapat dalam suatu sertifikat elektronik. Sehingga, makna dari kata mensertifikasi terkait dengan kewenangan mensertifikasi yang dapat dilakukan oleh Notaris adalah Notaris sebagai pihak ketiga yang dipercaya memiliki wewenang untuk memastikan suatu kebenaran dari sertifikat elektronik. Kebenaran yang perlu dipastikan oleh Notaris ialah meliputi kebenaran dari tanda tangan elektronik, kebenaran yang dimaksud adalah benar merupakan tanda tangan dari para pihak atau dapat dikatakan para pihak tersebutlah yang memang benar-benar telah memberikan tanda tangannya kedalam sertifikat elektronik tersebut sehingga kebenaran dari tanda tangan dapat dijamin karena dalam penandatanganan sertifikat tersebut tidak dilakukan oleh orang lain. Selanjutnya, selain mengenai kebenaran tanda tangan, notaris juga memastikan adanya kebenaran status atau identitas dari para pihak, serta memastikan kebenaran tanggal pada sertifikat elektronik tersebut. Kewenangankewenangan sebagaimana yang telah diuraikan tersebut sama dengan kewenangan Notaris yang diatur dalam Pasal 15 ayat (2) huruf a UUJNP, yang memberikan kewenangan kepada Notaris untuk "mengesahkan tanda tangan dan menetapkan kepastian tanggal surat dibawah tangan dengan mendaftarkan dalam buku khusus" atau dapat disebut juga dengan melakukan legalisasi. 22

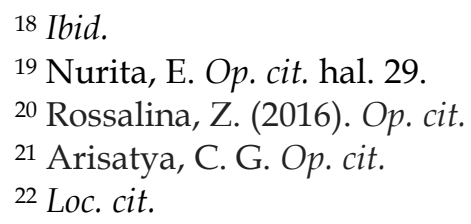


Kewenangan melakukan sertifikasi yang dimiliki oleh notaris terhadap transaksi yang dilaksanakan dengan cara elektronik sama dengan kewenangan notaris dalam melakukan legalisasi. Sejalan dengan kewenangan tersebut bentuk pertanggungjawaban notaris dalam melakukan sertifikasi juga sama seperti bentuk pertanggungjawaban notaris dalam melakukan legalisasi, sehingga dalam melakukan sertifikasi pertanggungjawaban notaris terletak pada kebenaran yang terdapat dalam sertifikat elektronik tersebut, kebenaran yang dimaksud adalah tanda tangan yang termuat pada sertifikat tersebut, sehingga dalam penandatangan sertifikat tersebut tidak dilakukan oleh orang lain atau orang yang bukan merupakan para pihak yang berwenang untuk memberikan tanda tangan. ${ }^{23}$ Serta, tanggal yang dipergunakan oleh notaris adalah tanggal pada saat para pihak menandatangani sertifikat elektronik tersebut.

Kewenangan mensertifikasi yang dimiliki oleh Notaris merupakan bagian dari cyber notary. Hal tersebut dikarenakan konsep cyber notary, apabila ditelusuri lebih jauh, merupakan suatu konsep yang memiliki arti lebih luas dari sekedar kewenangan notaris dalam melakukan sertifikasi. Dalam konsep cyber notary tersebut pelaksanaannya tidak terlepas dari adanya penggunaan maupun pemanfaatan teknologi informasi dalam melaksanakan jabatan yang dilakukan oleh Notaris. Sehingga, Notaris yang melaksanakan kewenangannya terkait mensertifikasi transaksi yang dilaksanakan secara elektronik tersebut dapat dikatakan sebagai salah satu bagian dari kewenangan notaris, yang termasuk kedalam lingkup cyber notary.

\section{Kesimpulan}

Kewenangan Notaris dalam mensertifikasi transaksi yang dilakukan secara elektronik sama dengan kewenangan untuk melakukan legalisasi yang dimiliki oleh Notaris, kewenangan tersebut meliputi kewenangan untuk memastikan kebenaran sertifikat terutama tanda tangan yang terdapat pada sertifikat, sehingga tanda tangan yang terdapat pada sertifikat tersebut dapat dipastikan merupakan tanda tangan dari para pihak dan tidak ditandatangani oleh orang lain, selain itu, status maupun identitas para pihak juga harus dipastikan kebenarannya, berikut tanggal pada sertifikat elektronik tersebut. Serta bentuk pertanggungjawaban notaris terkait kewenangannya dalam melakukan sertifikasi tersebut sama dengan pertanggungjawaban notaris dalam melakukan legalisasi.

\section{Daftar Pustaka / Daftar Referensi}

Buku:

Makarim, E. (2003), Kompilasi Hukum Telematika, Jakarta: Raja Grafindo Persada.

Mansur, D.M.A. \& Gultom, E. (2009), Cyber Law, Aspek Hukum Teknologi Informasi, cet-2, Bandung: Refika Aditama.

23 Lombogia, I. (2019). TINJAUAN YURIDIS PEMBUKTIAN LEGALISASI (WAARMERKING) AKTE BAWAH TANGAN BERDASARKAN UNDANG-UNDANG NOMOR 2 TAHUN 2014 TENTANG JABATAN NOTARIS. LEX ET SOCIETATIS, 7(1). 
Nurita, E. (2012), Cyber Notary Pemahaman Awal Dalam Konsep Pemikiran, Bandung: PT Refika Aditama.

Jurnal:

Arisatya, C. G. (2015). Urgensi dan Relevansi Kewenangan Notaris untuk Mensertifikasi Transaksi yang Dilakukan secara Elektronik (Studi di Notaris Wilayah Kerja Kota Malang). Kumpulan Jurnal Mahasiswa Fakultas Hukum.

BENNY, B. (2015). Penerapan Konsep Cyber Notary di Indonesia Ditinjau dari Undang-undang Nomor 2 Tahun 2014. PREMISE LAW JURNAL, 5.

Dharmawan, N. K. S. (2015). Keberadaan Pemegang Saham Dalam Rups Dengan Sistem Teleconference Terkait Jaringan Bermasalah Dalam Perspektif Cyber Law. Jurnal Magister Hukum Udayana (Udayana Master Law Journal), 4(1).

Gerungan, L. K. (2012). Kekuatan Pembuktian Akta Di Bawah Tangan Yang Telah Memperoleh Legalitas Dari Notaris.

Juwita, N. (2013). Kesalahan Ketik dalam Minuta Akta Notaris yang Salinannya Telah Dikeluarkan. CALYPTRA, 2(2), 1-20.

Lombogia, I. (2019). TINJAUAN YURIDIS PEMBUKTIAN LEGALISASI (WAARMERKING) AKTE BAWAH TANGAN BERDASARKAN UNDANGUNDANG NOMOR 2 TAHUN 2014 TENTANG JABATAN NOTARIS. LEX ET SOCIETATIS, 7(1).

Makarim, E. (2015). Keautentikan Dokumen Publik Elektronik Dalam Administrasi Pemerintahan Dan Pelayanan Publik. Jurnal Hukum \& Pembangunan, 45(4), 508570.

Rossalina, Z. (2016). Keabsahan Akta Notaris Yang Menggunakan Cyber Notary Sebagai Akta Otentik. Kumpulan Jurnal Mahasiswa Fakultas Hukum.

Rositawati, D., Utama, I. M. A., \& Kasih, D. P. D. (2017). PENYIMPANAN PROTOKOL NOTARIS SECARA ELEKTRONIK DALAM KAITAN CYBER NOTARY. Acta Comitas: Jurnal Hukum Kenotariatan, 172-182.

Wijanarko, F. R., Mulyoto, M., \& Supanto, S. (2015). Tinjauan Yuridis Akta Notaris Terhadap Pemberlakuan Cyber Notary Di Indonesia Menurut Undang-undang Nomor 2 Tahun 2014. Repertorium, 2(2).

Disertasi/Tesis:

Matra, A. F. (2012). Penerapan Cyber Notary di Indonesia Ditinjau dari Undang-undang Nomor 30 Tahun 2004 tentang Jabatan Notaris (Doctoral dissertation, Tesis, Depok).

\section{Peraturan Perundang-Undangan:}

Undang-Undang Republik Indonesia Nomor 2 Tahun 2014 Tentang Perubahan Atas Undang-Undang Nomor 30 Tahun 2004 Tentang Jabatan Notaris. (Lembaran Negara Republik Indonesia Tahun 2014 Nomor 3, Tambahan Lembaran Negara Republik Indonesia Nomor 5491).

Undang-Undang Republik Indonesia Nomor 11 Tahun 2008 Tentang Informasi dan Transaksi Elektronik. (Lembaran Negara Republik Indonesia Tahun 2008 Nomor 58, Tambahan Lembaran Negara Republik Indonesia Nomor 4843).

Undang-Undang Republik Indonesia Nomor 40 Tahun 2007 Tentang Perseroan Terbatas. (Lembaran Negara Republik Indonesia Tahun 2007 Nomor 106, Tambahan Lembaran Negara Republik Indonesia Nomor 4756). 
Peraturan Pemerintah Republik Indonesia Nomor 82 Tahun 2012 Tentang Penyelenggaraan Sistem Dan Transaksi Elektronik. (Lembaran Negara Republik Indonesia Tahun 2012 Nomor 189, Tambahan Lembaran Negara Republik Indonesia Nomor 5348). 